\title{
IL7R wt Allele
}

National Cancer Institute

\section{Source}

National Cancer Institute. IL7R wt Allele. NCI Thesaurus. Code C51369.

Human IL7R wild-type allele is located within 5p13 and is approximately $20 \mathrm{~kb}$ in length.

This allele, which encodes interleukin-7 receptor alpha chain protein, is involved in V(D)J recombination during lymphocyte development. 